\title{
Kinetics and Mechanism of Oxidation of Some Substituted Phenol by Imidazolium Fluorochromate in Aqueous Acetic Acid
}

\author{
S N Hallale ${ }^{\text {a }}$, S. B. Patwari ${ }^{\mathrm{b}}$, G G Mandawad ${ }^{\mathrm{a}}$ \\ ${ }^{1}$ PG Department of Chemistry Maharashtra Udayagiri, Mahavidyalaya, Udgir- 413517 \\ ${ }^{2}$ Department of Chemistry, LBS College, Dharmabad
}

\begin{abstract}
The Kinetics of Oxidation of p-methoxy phenol, p-cresol and p-Chloro phenol by Imidazolium Fluorochromate has been investigated in 50\%. Acetic acid. The order of reaction with respect to phenol and IFC was found to be one. The reaction rate increases with increase in $\left[\mathrm{HClO}_{4}\right]$ and the order of reaction with respect to $\left[\mathrm{H}^{+}\right]$was found to be one. The effect of addition of $\mathrm{NaCl}$ on the rate was found negligible. An increase in the percentage of acetic acid increases the rate of reaction. From the Hamett Plot, it was found that there is an increase in the rate of reaction for electron donating substituent while decrease in rate in the case of electron withdrawing substituents. The effect of temperature on the rate has been studied has been studied at four different temperatures and activation parameters were evaluated. On the basis of observed data, a probable mechanism is proposed.
\end{abstract}

Keywords: Phenol, oxidation, Imidazolium, Fluorochromate, Kinetics

\section{Introduction}

The chromium (VI) reagents containing heterocyclic base such as pyridinium chlorochromate ${ }^{1}$, pyridinium Flurochromate $^{2}$, quinolinium Flurochromate ${ }^{3}$, quinolinium bromochromate ${ }^{4}$, imidazolium flurochromate ${ }^{5}$, quinaldinium Flurochromate, quinaldinium dichromate ${ }^{6,7}$ etc. have been used for the study of oxidation of various organic substrates. Imidazolium flurochromate is highly selective, mild and stable oxidizing agent. Kinetics of oxidation of Thioacids, Methyl Phenyl Sulphides, Benzaldehyde, Methionine, Diols, Oximes, Anilines by IFC was reported. ${ }^{8-15}$ In this article we report the kinetics of oxidation of some para substituted phenols by IFC in aqueous acetic acid.

\section{Experimental}

All the chemicals used were of AR grade and Acetic Acid was purified by the method of Orton and Bradfield. All the stock solutions were prepared by dissolving known amount of samples in doubly distilled water. Imidazolium Flurochromate was prepared by the reported method ${ }^{5}$ and purity was checked by iodometric method. The perchloric acid $(60 \%$ Merck) was used to study the effect of acid strength on the rate of reaction.

All the kinetic measurements were carried out at 303K. First of all, the reaction vessels were kept in thermostatic bath to attain the equilibrium. The reaction was carried out under pseudo first order conditions by keeping large excess of Phenol over IFC. The known volume of IFC was rapidly added to the reaction mixture containing phenol, perchloric acid and water. The progress of the reaction was followed potentiometrically by setting up a cell made up of reaction mixture in which the platinum electrode and reference electrode (SCE) were dipped. The emf of the cell was measured after regular intervals of time by using equiptronics digital potentiometer., the pseudo first order rate constant were evaluated from the plot of $\log (\mathrm{emf})_{\text {time }}$ versus time

\section{Stoichimometry and Product Analysis:}

The oxidation of phenol by IFC leads to the formation of corresponding ketones. The stoichiometry of the reaction was determined by keeping known excess of IFC over substrates in 50\% acetic acid and perchloric acid was added. The reaction mixture was kept for 24 hours to ensure the completion of the reaction. Estimation of the unconsumed IFC showed that one mole of phenol consumes one mole of IFC.

The product analysis was made by monitoring TLC. The product was confirmed by noting the melting point of corresponding quinone $\left(\mathrm{M} P-75^{\circ} \mathrm{C}-77^{\circ} \mathrm{C}\right)$ and compared with the authentic sample. Then the product obtained was mixed with the authentic sample there no change in the melting point was observed.

\section{Result and Discussion}

The data of the kinetics of oxidation of some para substituted phenols by IFC at different initial concentrations of the substrate, IFC and $\mathrm{HClO}_{4}$ by keeping all other concentrations constant are discussed below.

\section{Effect of [Substrate]:}

The effect of concentration of the substrate on the rate of reaction was studied by varying the concentration of substrate at fixed [IFC], $\left[\mathrm{H}^{+}\right]$and constant temperature. The concentration of the substrate was varied in the range $2 \times 10^{-}$ 2 to $10 \times 10^{-2} \mathrm{~mol} \mathrm{dm}^{-3}$. It was found that increase in [Substrate] increases the rate of reaction. (Table 1). The plot of $\log \mathrm{k}_{\mathrm{obs}}$ versus $\log$ [substrate] was linear with slope $=$ $0.955\left(\mathrm{R}^{2}=0.9520\right)$ indicates the order of reaction with respect to substrate is one (Fig:1). The second order rate constants are constant supports the first order dependence on [substrate].

\section{Volume 4 Issue 12, December 2015}




\section{International Journal of Science and Research (IJSR) \\ ISSN (Online): 2319-7064}

Index Copernicus Value (2013): 6.14 | Impact Factor (2014): 5.611

Effect of [Oxidant]:

At fixed $\left[\mathrm{H}^{+}\right]$and by keeping substrate in excess, the effect of IFC concentration on the rate were studied by varying the [IFC] in the range $2 \times 10^{-3}$ to $10 \times 10^{-3} \mathrm{~mol} \mathrm{dm}^{-3}$. The plot of $\log E_{t}$ versus time was linear indicates first order dependence of the rate on IFC. The pseudo first order rate constant computed by varying [IFC] were found constant. (Table 1).

\section{Effect of $\left[\mathrm{HClO}_{4}\right]$ :}

The effect of added perchloric acid on the pseudo first order rate constant was studied at fixed [substrate], [IFC], ionic strength. Table 1 shows that the rate of reaction increases with iecrease in $\left[\mathrm{HClO}_{4}\right]$ solution. The plot of $\log \mathrm{k}_{\text {obs }}$ versus $\log \left[\mathrm{H}^{+}\right]$was linear with slope equal to unity indicates the reaction is first order with respect to $\left[\mathrm{H}^{+}\right]$Fig 2.This indicates the involvement of protonated IFC in the reaction.
Table 1: Effect of variation of [substrate], [IFC] and

[ $\left.\mathrm{HClO}_{4}\right]$ Acetic acid: $\mathrm{H}_{2} \mathrm{O}(50: 50) \mathrm{T}=303 \mathrm{~K}$

\begin{tabular}{|c|c|c|c|c|c|}
\hline $\begin{array}{c}10^{2}[\text { substrate }] \\
\mathrm{mol} \mathrm{dm}^{-3}\end{array}$ & $\begin{array}{c}10^{3}[\mathrm{IFC}] \\
\mathrm{mol} \mathrm{dm}^{-3}\end{array}$ & $\begin{array}{c}10\left[\mathrm{HClO}_{4}\right] \\
\mathrm{mol} \mathrm{dm}^{-3}\end{array}$ & \multicolumn{3}{|c|}{$10^{4} \mathrm{k}_{\text {obs }} \mathrm{s}^{-1}$} \\
\hline 2 & 2 & 2 & 4.14 & 3.86 & 2.04 \\
\hline 4 & 2 & 2 & 7.57 & 5.59 & 3.61 \\
\hline 6 & 2 & 2 & 11.21 & 8.39 & 5.23 \\
\hline 8 & 2 & 2 & 16.25 & 12.25 & 7.85 \\
\hline 10 & 2 & 2 & 23.73 & 18.14 & 11.93 \\
\hline 10 & 2 & 1.5 & 15.92 & 12.25 & 8.64 \\
\hline 10 & 2 & 1 & 11.13 & 7.66 & 5.76 \\
\hline 10 & 2 & 0.5 & 7.42 & 5.14 & 3.89 \\
\hline 2 & 4 & 2 & 4.15 & 3.75 & 2.10 \\
\hline 2 & 6 & 2 & 4.49 & 3.70 & 2.09 \\
\hline 2 & 8 & 2 & 4.02 & 3.69 & 2.03 \\
\hline 2 & 10 & 2 & 4.05 & 3.65 & 2.00 \\
\hline 10 & 02 & 2 & $23.64^{\mathrm{a}}$ & $17.95^{\mathrm{a}}$ & $11.93^{\mathrm{a}}$ \\
\hline 10 & 02 & 2 & $21.54^{\mathrm{b}}$ & $16.16^{\mathrm{b}}$ & $10.05^{\mathrm{b}}$ \\
\hline
\end{tabular}

a-Contain $0.001 \mathrm{~mol} \mathrm{dm}^{-3}$ Acrylonitrile b-Contain $0.0005 \mathrm{~mol} \mathrm{dm}^{-3} \mathrm{MnSO}_{4}$

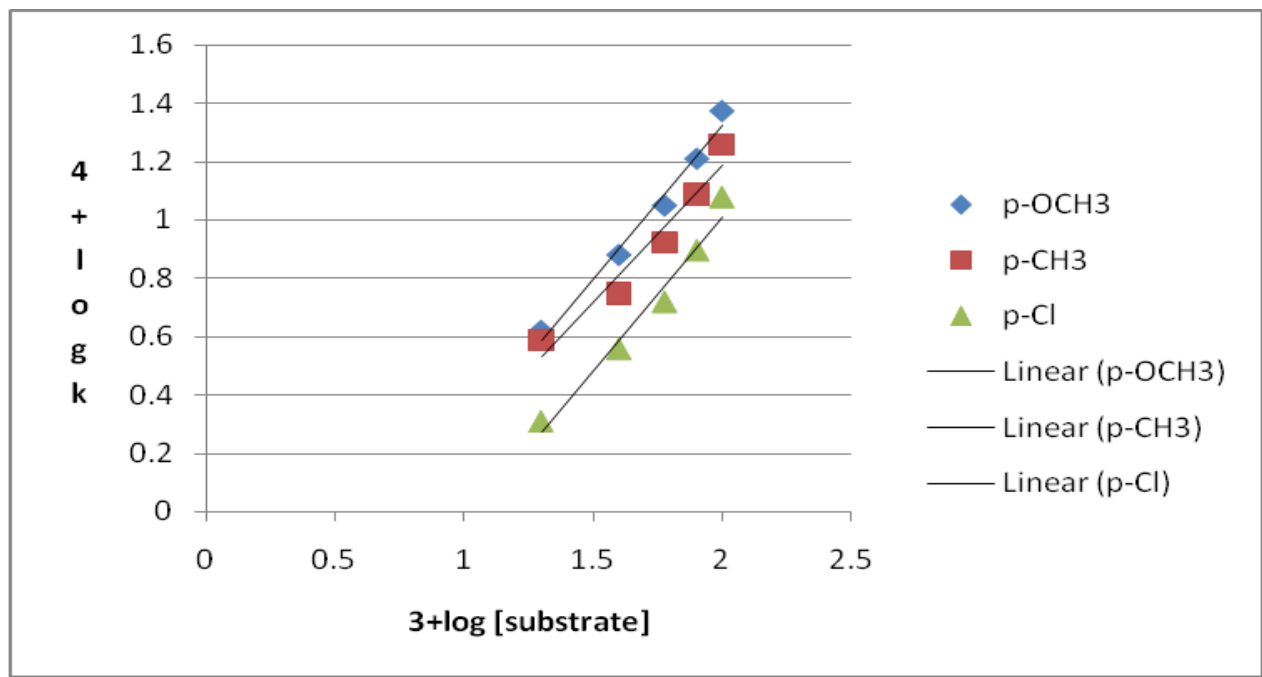

Figure 1

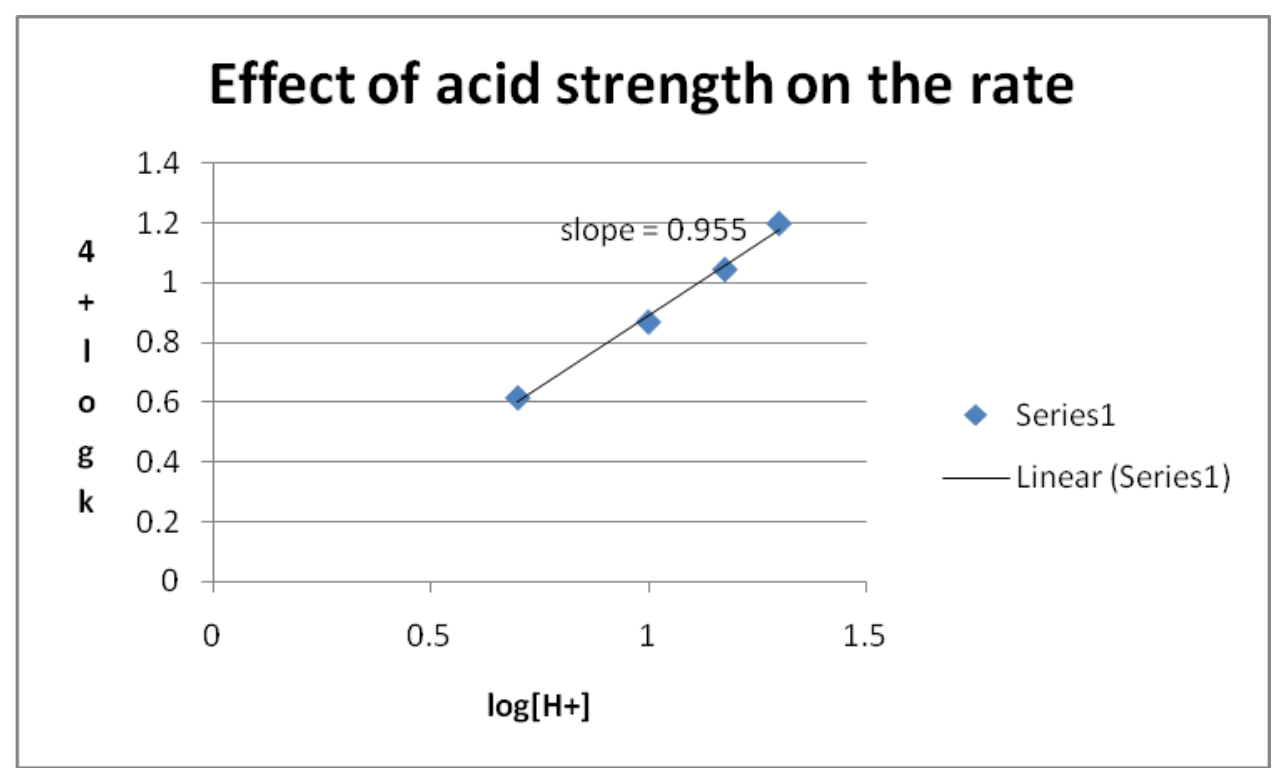

Figure 2

Volume 4 Issue 12, December 2015 


\section{International Journal of Science and Research (IJSR) \\ ISSN (Online): 2319-7064}

Index Copernicus Value (2013): 6.14 | Impact Factor (2014): 5.611

Effect of ionic strength:

The effect of ionic strength of the medium was studied by varying $[\mathrm{NaCl}]$. An increase in ionic strength of the medium on the rate of reaction was negligible. This indicates the involvement of neutral molecule in the rate determining step.

\section{Effect of Solvent Composition:}

The effect of change in the solvent composition on the pseudo first order rate constant was studied at fixed[Substrate], [IFC], $\left[\mathrm{H}^{+}\right]$and temperature. The reaction rate were determined at different $\%$ compositions of Acetic acid. It was found that the rate of reaction increases significantly with increase in the \% compositions of Acetic acid. It was found that the decrease in dielectric constant of the reaction medium increases the rate of reaction. (Table 2) A plot of $\log \mathrm{k}$ against 1/D was linear with positive slope indicates the involvement of reaction between ion and molecule Fig 3.

Table 2: Effect of solvent composition $10^{2}$ [substrate] $=2 \mathrm{~mol} \mathrm{dm}^{-3}\left[\mathrm{HClO}_{4}\right]=0.2 \mathrm{~mol} \mathrm{dm}^{-3}$ $10^{3}[\mathrm{IFC}]=2 \mathrm{~mol} \mathrm{dm}^{-3} \mathrm{~T}=303 \mathrm{~K}$

\begin{tabular}{|c|c|c|c|c|}
\hline \% Acetic acid : Water & $10^{3} 1 / \mathrm{D}$ & \multicolumn{3}{|c|}{$10^{4} \mathrm{k}_{\text {obs }} \mathrm{S}^{-1}$} \\
\cline { 3 - 5 } & & $\mathrm{p}-\mathrm{OCH}_{3}$ & $\mathrm{p}-\mathrm{CH}_{3}$ & $\mathrm{p}-\mathrm{Cl}$ \\
\hline $50: 50$ & 26.66 & 4.14 & 3.86 & 2.04 \\
\hline $55: 45$ & 28.77 & 4.88 & 4.47 & 2.24 \\
\hline $60: 40$ & 31.74 & 5.72 & 5.19 & 2.44 \\
\hline $65: 35$ & 35.04 & 6.75 & 6.05 & 2.71 \\
\hline $70: 30$ & 37.03 & 7.95 & 7.04 & 3.02 \\
\hline
\end{tabular}

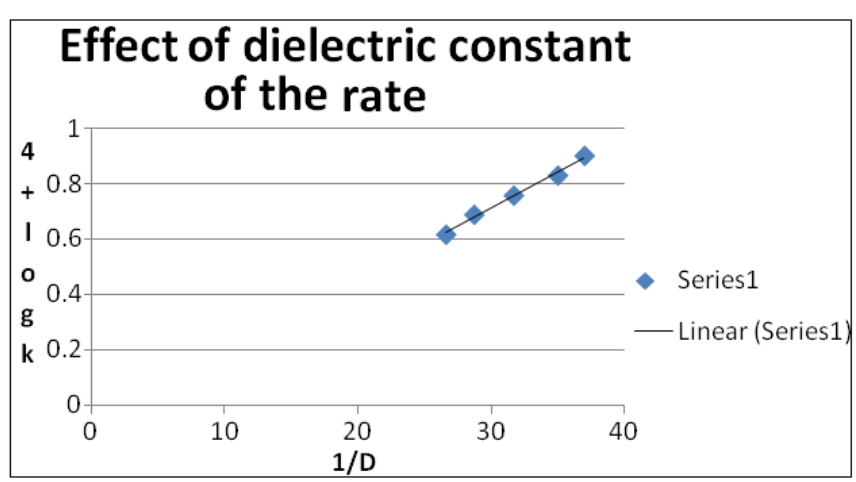

Figure 3

\section{Effect of Temperature}

The effect of temperature on the rate of reaction were studied in the temperature range $303 \mathrm{~K}$ to $318 \mathrm{~K}$ by keeping the concentration of all reactants constant. An increase in temperature increases the rate of reaction. The activation parameters were calcuated from the plot of $\log \mathrm{k}_{2}$ versus $1 / \mathrm{T}$ $\mathrm{K}^{-1}$. Fig:4

The second order rate constants were obtained as $\mathrm{k}_{2}=\mathrm{k}_{\mathrm{obs}} /$ [Phenol] (Table 3)

Table 3: Effect of temperature and activation parameters at $303 \mathrm{~K}$

$10^{2}$ [substrate $]=10 \mathrm{~mol} \mathrm{dm}^{-3}[\mathrm{HClO} 4]=0.2 \mathrm{~mol} \mathrm{dm}^{-3}$ $10^{3}[\mathrm{IFC}]=2 \mathrm{~mol} \mathrm{dm}^{-3}$

\begin{tabular}{|c|c|c|c|}
\hline \multirow{2}{*}{$\begin{array}{c}\text { Temperature } \\
\mathrm{K}\end{array}$} & \multicolumn{3}{|c|}{$10^{2} \mathrm{k}_{2} \mathrm{dm}^{3} \mathrm{~mol}^{-1} \mathrm{~s}^{-1}$} \\
\cline { 2 - 4 } & $\mathrm{p}-\mathrm{OCH}_{3}$ & $\mathrm{p}-\mathrm{CH}_{3}$ & $\mathrm{p}-\mathrm{Cl}$ \\
\hline 303 & 2.373 & 1.81 & 1.19 \\
\hline 308 & 2.96 & 2.34 & 1.81 \\
\hline 313 & 3.67 & 3.01 & 3.01 \\
\hline 318 & 4.51 & 3.88 & 4.99 \\
\hline $\mathrm{E}_{\mathrm{a}} \mathrm{KJ} \mathrm{mol}^{-1}$ & 34.88 & 40.38 & 81.65 \\
\hline$\Delta \mathrm{H}^{\mp} \mathrm{KJ} \mathrm{mol}^{-1}$ & 32.36 & 37.87 & 79.11 \\
\hline$-\Delta \mathrm{S}^{\mp} \mathrm{J} \mathrm{mol}^{-1}$ & 177.56 & 160.39 & 18.47 \\
\hline$\Delta \mathrm{G}^{\mp} \mathrm{KJ} \mathrm{mol}^{-1}$ & 88.60 & 86.46 & 84.77 \\
\hline Log A & 4.39 & 5.23 & 11.55 \\
\hline
\end{tabular}

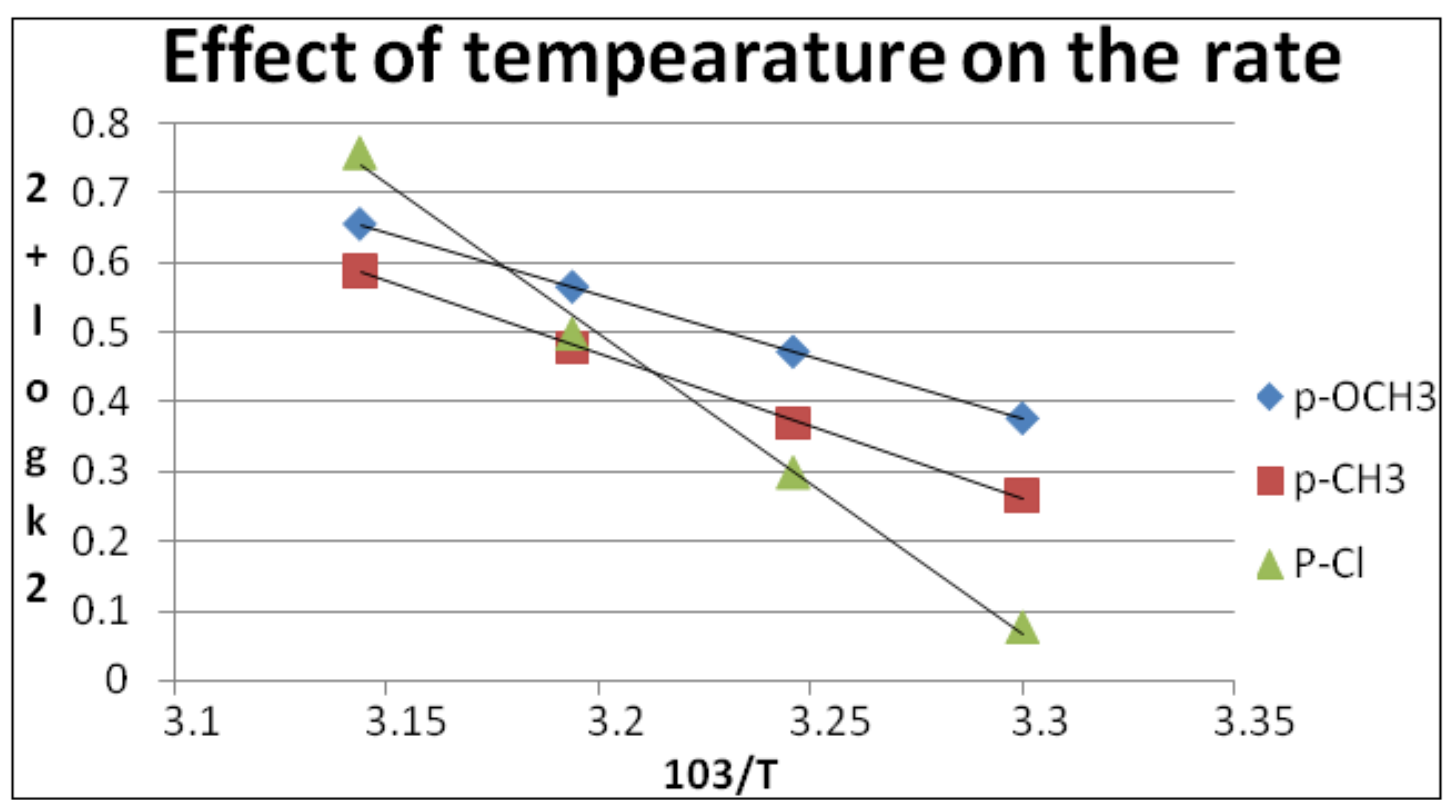

Figure 4 


\section{International Journal of Science and Research (IJSR) \\ ISSN (Online): 2319-7064 \\ Index Copernicus Value (2013): 6.14 | Impact Factor (2014): 5.611}

\section{Discussion}

From the observed kinetic data, the reaction follows first order Kinetics with respect to IFC, Phenol and $\mathrm{HClO}_{4}$. The double reciprocal plot of plot of $1 / \mathrm{k}_{\mathrm{obs}}$ versus $1 / /$ [substrate] was a straight line with positive intercep suggests that the reaction proceeds with the formation of the complex between oxidant and substrate and follows the Michaelis Menten mechanism. Increase in rate of reaction with decrease in dielectric constant suggests that the reaction is of ion-dipole type ${ }^{16}$. This suggests that the transition state is more polar than the reactants. There was no change in the rate of reaction with change in the ionic strength of the medium . This indicates the involvement of neutral molecule in the rate determining $\operatorname{step}^{17}$.The rate of reaction increases with increase in concentration of perchloric acid suggests that the protonated $\left(\mathrm{IFCH}^{+}\right)$is involved in the rate determining step. ${ }^{18,19}$

The activation energy, entropy, and enthalpy for oxidation of the para substituted phenols were calculated. The high negative values of the entropy suggests that the transition state is more ordered than the reactants due to increase in solvation. The high values of free energy of activation and enthalpy of activation suggests that highly solvated transition state is existed. The Exner plot of $\log \mathrm{k}_{2}(308 \mathrm{~K})$ versus $\log \mathrm{k}_{2}(303 \mathrm{~K})$ was linear $\left(\mathrm{R}^{2}=0.9612\right)$ and the isokinetic temperature evaluated was $313.32 \mathrm{~K} . .^{20}$ This suggests that the decomposition of Michaelis- Menten complex follows the similar mechanism for all phenols. The reaction constant $\rho$ can be determined from the slope of Hamett linear plot of log k versus $\sigma$ values of the substituent as reaction constant $\rho=-0.636$ indicates that the electron donating substituent accelerates the rate while electron withdrawing substituent retards the rate and probably this may be due to the stabilization of electron deficiency at the reaction centre of electron donating groups and due to decrease in electron density at the reaction centre for electron withdrawing group. ${ }^{21}$ The order of reactivity is $\mathrm{p}-\mathrm{O}$ $\mathrm{CH}_{3}>$ p- $\mathrm{CH}_{3}>$ p- $\mathrm{Cl}$ substituted phenol. No change in the rate of reaction by the addition of acrylonitrile ruled out the operation of free radical mechanism. The rate of reaction was retarded by the addition of $\mathrm{Mn}$ (II) suggests the involvement of two electron transfer in the reaction. The free energy of activation were found to be almost similar indicates that the similar mechanism is operative for all phenols.

\section{Conclusion}

The reaction between IFC and substituted phenol follows the first order dependence of the rate on IFC, phenol and $\mathrm{H}^{+}$. Decrease in dielectric constant of the medium increases the rate of reaction. The reaction is acid catalyzed and has stoichiometry $1: 1$. The oxidation of substituted phenol yields corresponding quinones. The rate of reaction accelerates for electron donating substituent whereas retards for electron withdrawing substituent. The negative $\Delta \mathrm{S}^{\neq}$gave support to the formation of highly ordered transition state. An almost similar $\Delta G^{\ddagger}$ values suggest the operation of similar mechanism is for all phenols.

\section{Mechanism}

An increase in rate with increase in acid strength suggests that the protonated IFC ions involved in the rate determining step.IFC is protonated in the first step which then forms complex with the substrate and decomposes to give product in the fast step. On the basis of experimental observations, the probable mechanism for the oxidation of phenol by IFC is suggested.

\section{Possible mechanism}

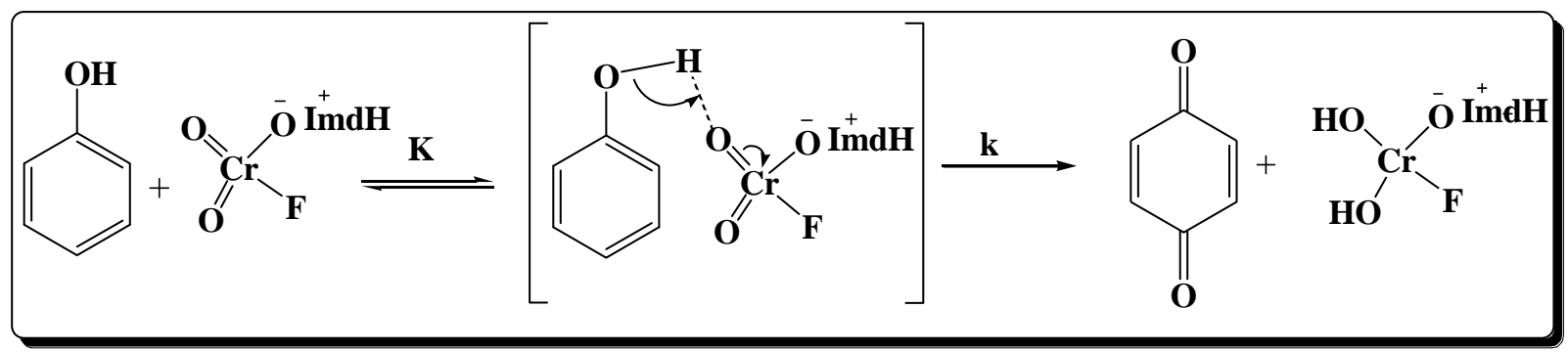

On the basis of the above mechanism, the rate law is Rate $=\mathrm{Kk}[$ Phenol $][\mathrm{IFC}]\left[\mathrm{H}^{+}\right]$

\section{References}

[1] Corey E. J. and Boger D.L., Tetrahedron Lett. 28, 1978, 2461

[2] Bhattacharjee M N Choudhari M K Dasgupta H S Rou N \& Khating D T, synthesis, 1982, 588.

[3] Pandurangan A, Murugesan V oxidation communi 1997, 20, 93.

[4] Dhariwal V, Yajurvedi D and Sharma P K Indian J chem., 2006, 45 A 1158.

[5] A Panduranga, G.A. Rajkumar, B Arabindaoo, V Murugesan, Indian J Chem, 38 B (1999) 99.
[6] K G Sekar ,R V Sakthivel,J Solution Chem 42 (2013),1748-1756

[7] Degirmenbasi N, Ozgun, B :Montasch. Chem. 135,407410 (2004)

[8] Bincy John, M. Pandeeswaran, D S Bhuvaneshwari and K P Elango J serb Chem Soc 71 (1) 2006, 19.

[9] D S Bhuvaneshwari and K P Elango J ind chem. Soc 86, 2009, 242.

[10]D Sharma, P Panchariya, Shweta Vyas, Int J of Chem 2012 1(1) 29-37.

[11]Deepika Baghmar, Pryanka Purohit, Shweta Vyas and Vinita Sharma, Int J Current Chem 2(1) 2011 9-18.

[12] Monica Gehilot, Mamta Gilla, PTSRK Prasad Rao and Vinita Sharma,- Int. J. Chem. Sci. 8(3) 2010. 1943-52.

\section{Volume 4 Issue 12, December 2015}




\section{International Journal of Science and Research (IJSR) \\ ISSN (Online): 2319-7064}

Index Copernicus Value (2013): 6.14 | Impact Factor (2014): 5.611

[13] NMI Alhaji, A Shajahan and G K Ayyadurai- Chem. Sci. Trans. 2(2) 2013, 429-434.

[14] Basim Asgar, S Sheik Mansoor, V Saleem Malik- Euro. Chem. Bull 2(8), 2013,538-544.

[15]D Baghmar, P Purohit, S Vyas and Vinita Sharma J, Ind. Coun. Chem. 27(2), 2010, 134.

[16]E S Amis "solvent effect on reaction rates and mechanism" Academic press New York 1967, 42.

[17] Palaniappan A N, Sekar K G and Ravishankar M, Oxidation Communication, 18, 52-57.

[18] Wiberg K B, Oxidation in organic chemistry part A ,Academic press, New York 1965.

[19] Banerjee K K, J Chem. Soc. Perkin Trans. 2, 1978, 639

[20] O Exner, Collect Chem. Czech Commun. 31, 1966, 3222.

[21] J Rajaram, J C Kuriacose, "Kinetics and Mechanism of Chemical Transformations" Macmillan India 1993, 393.

[22] Ahmed Al , Ajlouni, Andreja Bakac and James H Espenson- Inorg. Chem. American Chemical Society 32, 1993, 5792-5796.

[23] Reddy T S, Jagannadham V, Proce. Natl. Acad. Sci. India -56(A), 1986, 129.

[24] Banerjee K K, Bull. Chem. Soc. Japan 51, 1978, 2732

[25] D S Bhuvaneshari and K P Ealango, J. Ind. Chem. Soc. 86, 2009, 242. 